\title{
セメントレス人工膝関節の使用経験
}

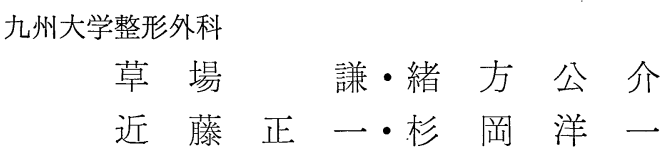

済生会八幡病院

内 藤 正 俊 - 黒木 健 文

瑇口病院

小川 昭一郎

\section{Cementless Total Knee Replacement}

by

\author{
Ken Kusaba, Kosuke Ogata, Masakazu Kondo, \\ Yoichi Sugioka \\ Department of Orthopedic Surgery, Faculty of Medicine \\ Kyushu University \\ Masatoshi Naito, Takefumi Kuroki \\ Orthopedic Surgery, Saiseikai Yahata Hospital
}

\section{and Syoichiro Ogawa}

Mizoguchi Hospital

In the past two years, we performed total knee replacement using three types of prostheses; Ceramic (13 patients), PCA (6), and ORTHOLOC (2) without cement. In the case of the ceramic total knee system, radiolucent line widely appeared around the components on the radiographs, and there was one case of fracture of the ceramic prosthesis. So we have discontinued to use this system recently. Both PCA and ORTHOLOC have a porous coating in order to stabilize the prosthesis by bony ingrowth. We analyzed merits and demerits in using bone cement in total knee replacement and we concluded that it is better to perform the total knee replacement without using cement. The follow-up periods of these series are too short to discuss the results, however, no serious complications have been encountered so far in the patients with PCA and ORTHOLOC knees.

\section{はじめに}

過去 10 年間, 人工膝関節の開発にはめざましいも のがあり, total condylar knee が出来て以来成績 あ向上してきた. しかし次々に新しいものが開発さ れ, 又合併症む多く報告されている為, そのどれを使 用するか選択に迷うことが多い. 最近骨セメントを使 用するために生じる種々の欠点をなくす為, セメント レス人工膝関節の開発が進がられている。我々はその 中でデザイン, 手術手技の点で共にすぐれていると思
われるセラミック（京セラ）〔図1], PCA（porouscoated anatomic) (Howmedica) [図 2], Whiteside の ORTHOLOC (Dow Corning) [図 3] の 3 つのタイプの total knee system を使用する機会を 得たので, その使用経験を報告すると共に, セメント を使わない利点について若干の考察を加える。

\section{臨 床 材 料}

セラミッッタイプが 13 例で 経過 観察期間は 6 力月 〜 2 年である。また過去 6 力月間にPCA タイプで 6 


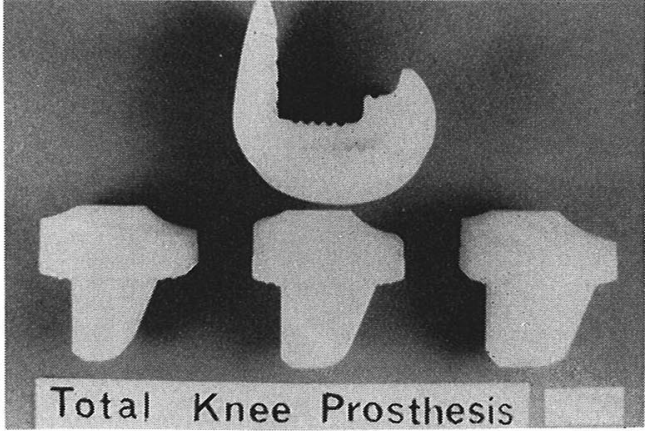

図1 セラミック

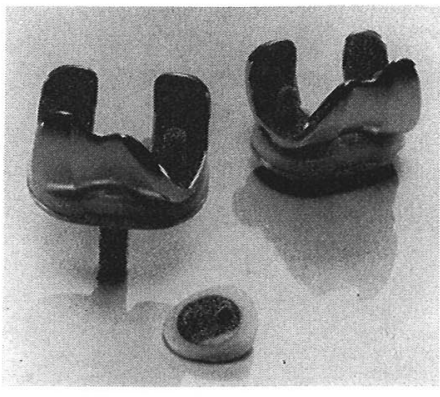

図 $2 P C A$

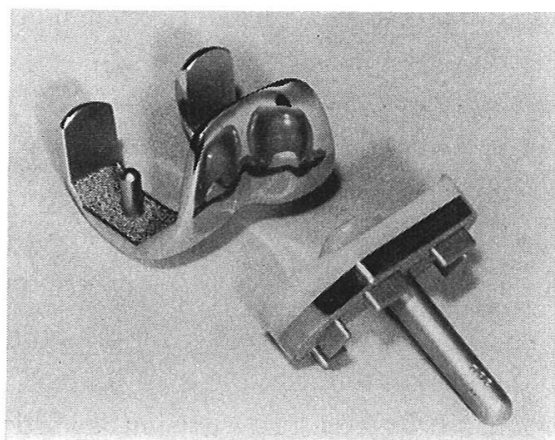

図3 ORTHOLOC

例, ORTHOLOC タイプ 2 例の人工膝関節置換術を施 行した. セラミックタイプ 13 例の内， 3 例の慢性関 節リウマチを除き，いずれも一次性変形性膝関節症の 症例である。

$$
\text { 症例 }
$$

( I ) セラミック

症例 144 才 男性

術後 3 カ月ですでに patellar component の一部

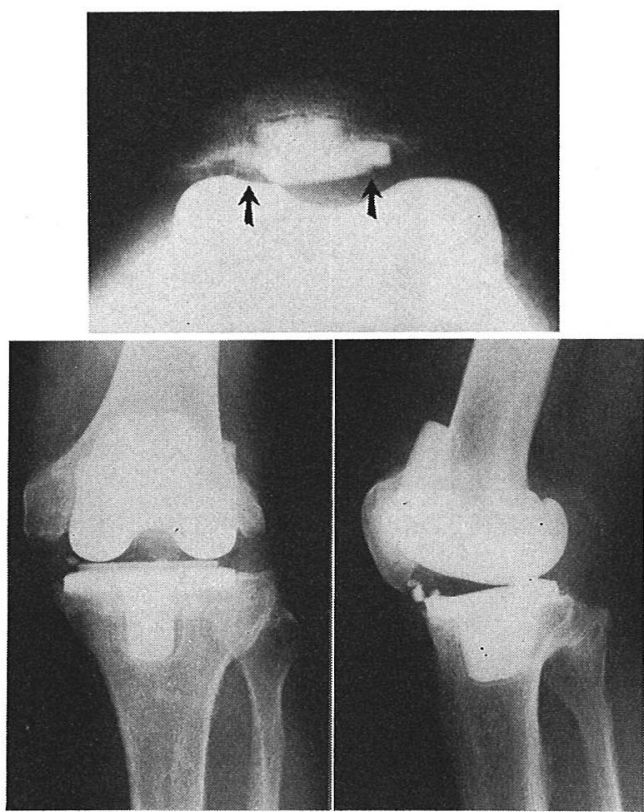

図4 症例 1 , 術後 20 力月（セラミック） component の破損がありその破片す見元る. 又, 周囲には著明な radiolucent line が広がっ ている.

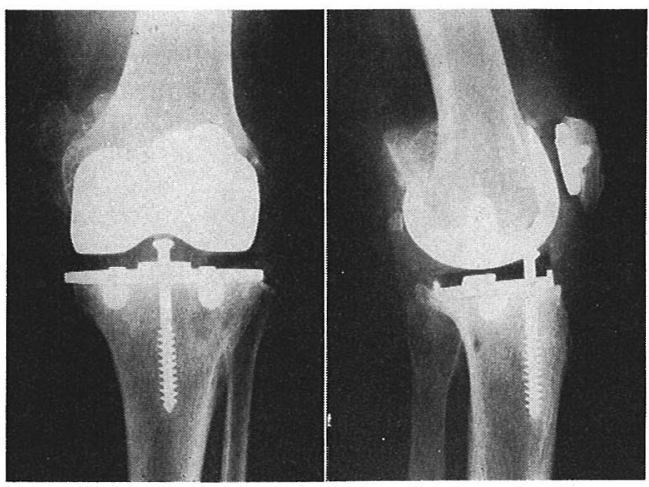

図 5 症例 2 , 術後 5 力月 (PCA) セメントレスの場合, とのように tibial component の固定に 1 本の screw を使用する.

に破損が見られた. 術後 20 カ月では破損は femoral component の一部にあ見られ，3つの component の周囲には radiolucent line が広がっている〔図 4]. ROM は術前屈曲 $100^{\circ}$, 伸展 $-10^{\circ}$ であつた が, 術後 20 力月で屈曲 $90^{\circ}$, 伸展 $0^{\circ}$ であつた.

(II) $\mathrm{P} \mathrm{C} \mathrm{A}$ 


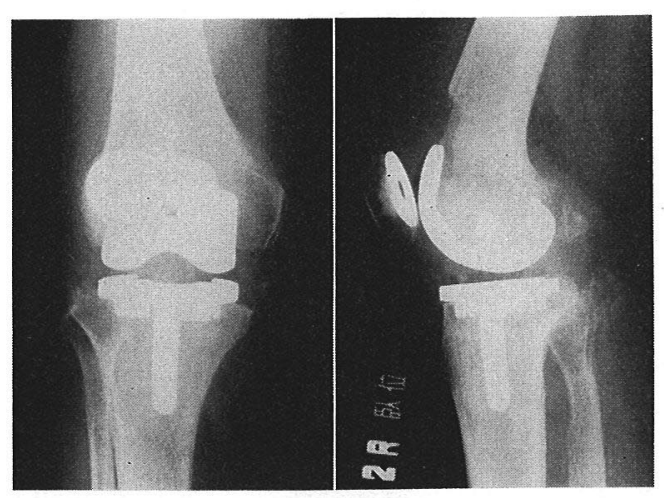

図6症例 3 , 術後 3 力月 (ORTHOLOC)

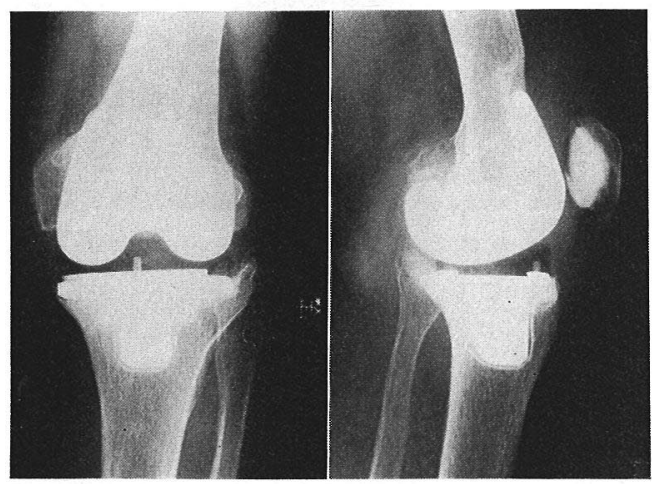

図 7 各コンポーネント周困に radiolucent line が広がっている。術後15力月(セラミック)

症例 273 才性

PCA タイプでセメントを使用しない例には tibial component 飞 1 本の screw を通し固定力を増強せ しめている〔図5〕，ROM は術前屈曲 $90^{\circ}$, 伸展 $0^{\circ}$ で, 術後 5 力月に扔いても屈曲 $90^{\circ}$, 伸展 $0^{\circ}$ であり, 経過良好であった。

(III) ORTHOLOC

症例 373 才男性

ROM は術前屈曲 $90^{\circ}$, 伸展 $0^{\circ}$, 術後 3 力月で屈曲 $90^{\circ}$, 伸展 $0^{\circ}$ であり, 経過良好である[図6].

考察

未だ症例数が少なく経過観察期間も短いので，それ ぞれの成績について検討する段階ではない，従って今 回は現時点に㧍ける問題点を述べると共に, セメント を使用しないととに関して若干の考察を加える。
セラミックタイプの total knee system は経過を 追っていると，X線上ほとんどの症例で, 症例 1 亿見 られたような component 周囲の radiolucent line が出現していた. radiolucent line は時間の経過と 共に広がりを見せ，特に tibial component の周囲 に強いものが数例認められた〔図 7 〕. 症例 1 のよう にセラミックの破損を来たした例があること，さらに 現在のセラミック人工関節では後十字靱帯を切断する ための生体力学上の欠点が考えられるので, 最近は使 用を見合わせている.しかしながらX線上の変化にあ かかわらず, 疼痛の改善や可動域等を観察すると, 哷 床的にはむしろ経過良好例が多く, 必ずしもX線所見 と臨床症状とが一致しない，乙れらの点の検討には今 後の長期予後調查が待たれる.

PCA total knee system は解剖学的に, かつ生体 力学的にヒトの正常膝により近づけるようデザインさ れた人工膝関節である。また海綿骨との接触面にはク ロムコバルトの平均 $425 \mu$ の porous coating が施 してあり，長期にわたる確実で強固な固定を期待して いる.

一方, Whiteside の ORTHOLOC total knee system の特徽は，手術手技が比較的煩雑である PCA タイプ (Universal Total Knee Instrumentation System を使用）に比べて容易であるてと，デザイン が簡略化されていることなどにある，ただしサイズが 日本人にはやや大きすぎるため，症例が限られてい る.乙れも海綿骨との接触面に porous coating が 施してあるが，PCA タイプでは海綿骨との全接触面 が porous coating されているのに対し, ORTHOLOC タイプでは大腿骨之脛骨との水平切骨面に対し てのみ porous coating されている. 荷重面に強固な 固定が獲得されていればよい, revision の際拔去が 容易で必要以上に骨を除去しないでよい，等の理由に よるもの上考えられている.

これら PCA, ORTHOLOC 両タイプの人工膝関節 置換術は未だ経過観察期間が短いが，セメントを使用 しなかったいずれの症例でも早期荷重による component の loosening は認めていない. しかしセメン 卜を使用しないため，術中術後の出血が $400 \sim 1,500$ $\mathrm{ml}$ 之比較的大量であった. 特汇術後の出血量が多く, 結局輸血を余儀なくされた例が両者 8 例中 3 例であっ た，骨口ウなどで術中骨㗙から出血の止血操作を行っ ているが効果は十分ではなかったため, 最近では術 
後の suction drainage をやめ straight gravity drainage のみに変更している. これで相当量の術後 出血が減少している.

今回すべての症例にセメントを使用しなかったわけ ではない，使わないですむには一定の条件を満たして いる必要がある. すなわち第 1 亿接触面の骨の性状が 問題で, 例えばそてが硬化変性像を呈していた場合生 物学的な成長が期待出来ず, 人工関節の固定が弱くな る.したがって健常な骨であることが望ましい，第 2 点は置換終了時の component の安定性である. 即 ち不安定な component と骨との間には強固な固定 は期待出来ないのである.

セメントを使わない利点としては，手術時間の短 縮, wear debris が出来ない, 感染の機会が減る, loosening や感染などにより再手術を余儀なくされた 場合, 骨の除去を最少限に留めることが出来, 容易で ある. 長期にわたる 安定性が期待できる，海綿骨の devascularization が起こらない, またセメント圧入 時の血圧低下，脂肪塞栓等の心配がない，などをあげ ることが出来る.

セメントを用いず porous coating された人工関節 を使用すれば，骨との間が生物学的に生きている状態 となり，長期にわたる強固な固定を期待出来る.とれ により体重や活動性の増加に対する耐用性を增し, 適 応年令を引き下げることが可能となるであろう.

数多い人工膝関節の中で我々はこの観点からデザイ ン，手術手技の点で共にすぐれていると思われている 3つのタイプ, 特に最近は PCA, ORTHOLOC タイ プの人工膝関節を使用している.

\section{ま と め}

1）最近我々が使用している人工膝関節について紹 介した.

2）適応があれば，セメントを用いない人工関節置 換術の方がすぐれていると思われる.

3) いずれも経過観察期間が短く, 特に PCA, ORTHOLOC では未だ 1 年に満たず，乙れらの長所 欠点は今後の調査研究にまたれる.

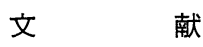

1) Borden, L. S. et al: Total condylar prosthesis. Orthop. Clin. North Am. 13 (1): 123-130, 1982.
2) Hungerford, D. S. et al.: The porouscoated anatomic total knee. Orthop. Clin. North Am. 13 (1): 103-122, 1982.

3) Hungerford, D. S. et al. : Preliminary experience with a total knee prosthesis with porous coating used without cement. Clin Orthop. 176: 95-107, 1983.

4) Insall, J. et al.: Total condylar knee replacement. Clin. Orthop. 120: 149-154, 1976.

5) Krause, W. R. et al. : Strength of the cement-bone interface. Clin. Orthop. 163: 290-299, 1982.

6）寺山和雄・他：骨セメントの長所欠点と骨セメ ントを使用しない人工関節に刘する批判. 整形外 科, 30: 188-191, 1979.

7）山本純已：骨セメントを使用する人工膝関節と 使用しない人工膝関節。整形外科, 30：175-177, 1979.

8)山本純已 - 他 : 人工 滕関節 置換術. 臨整外, 16:822-828, 1981.

質 問 久留米大学 井上 明生

6 力月〜 2 年の follow up study で, 人工膝関節 はセメントレスの方がよいという結論ですか.

解 答草場 謙

今回は使用経験を述べただけで，follow up study ではない。

質 問大分医科大学 鳥巣 岳彦

RAに対しては，どのように考えるのか。

解 答州大学 草場 謙

RA については，乙れまでに 3 例のみ，セラミック を使った症例がある.

RA の骨の性状を考えると，自らその indication は限られてくるあのと思われる.

\section{質 問長崎大学 岩崎 勝郎}

cementless 人工関節の場合の荷重歩行開始時期 は, cement を用いた場合に比べて早いかおそいか. その理由は?

解 答 九州大学 草場 謙 セメントを使わない症例と原則的には全く同様のプ ロトコールであるが，実際には荷重に対しては慎重に 対処している. 